\title{
A Grande Saúde e a Filosofia como Vivência (Erlebnis)
}

\author{
Jackson Daniel Adami*
}

Resumo: Aproximar vivência e criação de si explorando suas relações será um dos objetivos deste artigo, bem como elucidar a capacidade humana de dotar de sentido suas vivências, o que também não deixa de ser uma atitude artística perante a própria existência.

Palavras-chave: A gaia ciência, vivência, grande saúde, arte.

* Mestre em Filosofia pela Universidade Estadual do Oeste do Paraná (Unioeste), Toledo, PR, Brasil. ORCID https://orcid.org/0000-0002-8771-1379

Correio eletrônico: jacksondrm@hotmail.com 
Em alguns momentos, Nietzsche parece querer nos mostrar que o conhecimento só é possível enquanto vivência (Erlebnis). Do contrário não é conhecimento atuante, é mero saber conceitual. ${ }^{1}$ Nietzsche parece aproximar vivência e criação de si evidenciando a capacidade humana de dotar de sentido suas vivências, o que aponta para a possibilidade de uma atitude artística perante a própria existência. Desse modo, a arte ressurge em Nietzsche, após o rompimento com Wagner, sob uma roupagem mais oculta, insidiosa $\mathrm{e}$ sagaz; por isso mais atuante ${ }^{2}$; e parece estar aliada ao conhecimento. Todo aquele que vivencia a si mesmo, concomitantemente, expande seu próprio conhecimento e se constitui nessas vivências, ou seja, vivenciar-se é criar-se. ${ }^{3}$

1 "Quando em certa ocasião o Dr. Heinrich Von Stein queixou-se honestamente de não entender palavra do meu Zaratustra, disse-lhe que era natural haver compreendido seis frases dele, ou seja; tê-las vivido [erlebt], elevaria alguém a um nível bem superior [...]" (EH/EH, Por que escrevo tão bons livros, 1, KSA 6.298). Cabe fazer menção aqui à singularidade das vivências. Isto é, que elas são uma experiência muito própria. Com "experiência própria", não estamos nos referindo à noção de um sujeito subsistente ao qual a experiência pertencesse, mas sim a disposições de força peculiares a um organismo. Isso torna a vivência algo compreensível para uma determinada perspectiva, ou seja, para as disposições de força organizadas de um certo modo, tornando essas vivências incompreensíveis, em sua plenitude, para disposições distintas. Parece-nos ser justamente para esse sentido que aponta o subtítulo de Assim Falou Zaratustra: "Um livro para todos e para ninguém”. Nele conserva-se a universalidade da teoria perspectivística nietzschiana, ao mesmo tempo em que se preserva a singularidade das vivências ou experiências; sempre peculiares às disposições de força estabelecidas no momento da vivência.

2 Esta noção aqui apresentada possui origem no pensamento freudiano. Segundo ele, um impulso inconsciente possui uma influência muito maior sobre o indivíduo, posto que atuaria sub-repticiamente, por assim dizer. Ou seja, sem o controle e censura das faculdades superiores da consciência, como o super-ego, por exemplo. Em outras palavras, quanto mais inconscientemente atua um impulso, mais livremente ele o faz - pois não sofre as censuras e resistências das faculdades conscientes.

3 Os termos que utilizamos, tais como: "vivência de si", "criação de si", "vivenciar-se", "criar-se", dentre outras variações que eventualmente possam aparecer nesse artigo, direta ou indiretamente, podem sugerir que estejamos trabalhando a partir do substabelecimento de um sujeito. Gostaríamos de não apenas pontuar, mas frisar que todas as vezes em que nos reportamos à vivência, à experiência ou à criação e que atribuamos isso a um "si" ou a um "eu", o que se quer, precisamente, é evidenciar a singularidade da experiência. Um "si", poderíamos dizer, é uma organização e disposição de forças peculiares a um organismo. Esse, por sua vez, como o próprio Nietzsche apontou em seus cadernos, é uma unidade apenas enquanto organização: unidade que representa um, mas não é um: "Toda unidade só é unidade enquanto organização e jogo de conjunto [...] portanto uma formação de domínio que significa um, mas não é um.” (Nachlass/FP, 1885/1886, 2[87], KSA 12.104, nossa tradução). 
Adami, J. D.

Parece inviável falar sobre filosofia como vivência em Nietzsche sem reportar-se imediatamente à obra A Gaia Ciência. Nela, o pensador dá testemunho de sua convalescença, após um longo e insidioso/sorrateiro período de enfermidade. Nela Nietzsche enuncia a vivência de sua singularidade e tentaremos mostrar como a experiência da doença e da saúde se entretece com sua filosofia mais própria consolidando-se enquanto vivência filosófica.

Gaia ciência é um pathos que se manifesta em forma de fluidez e leveza decorrentes de uma superação; não deixa de ser também uma libertação e um contentamento alegre ante as intempéries. É uma aceitação de tudo que é amargo, uma aceitação de toda dor de tudo que é, que foi e será, porque tudo é necessário; negar uma parte da existência seria corrompê-la por completo. Esse pathos que é a proposta nietzschiana para gaia ciência -, com todos esses sentimentos, parece girar em torno de um ponto concêntrico: a convalescença. Quando se supera uma condição difícil, finalmente se toma conhecimento da própria força. Desejar não ter sofrido é um juízo muito raso acerca do sofrimento, uma avaliação obtusa e irrefletida que se restringe a meras questões de autoconservação e descura daquelas relativas ao âmago da existência que, para Nietzsche, consiste na intensificação do sentimento de potência. Vejamos o que o filósofo escreve acerca da sua convalescença:

Talvez não baste somente um prólogo para este livro; e afinal restaria sempre a dúvida de que alguém que não tenha vivido algo semelhante possa familiarizar-se com a vivência [Erlebnisse] deste livro mediante prólogos. Ele parece escrito na linguagem do vento que dissolve a neve: nele há petulância, inquietude, contradição, atmosfera de abril, de maneira que continuamente somos lembrados tanto da

\footnotetext{
Assim, o que garante a singularidade da experiência não é algum tipo de substrato ou essência, mas sim a multiplicidade das forças que permite a expressão destas de uma determinada maneira. A singularidade da experiência remete ainda, como o termo já o sugere, à peculiaridade vivenciada por uma determinada organização e disposição de forças, contudo, jamais se olvidando de que essa disposição decorre, precisamente, da multiplicidade de forças que se lhe opõem.
}

54| Cad. Nietzsche, Guarulhos/Porto Seguro, v.40, n.2, p. 52-73, maio/agosto, 2019. 
proximidade do inverno como da vitória sobre o inverno, a qual virá, tem de vir, talvez já tenha vindo... A gratidão aí emana sem parar, como se tivesse ocorrido o mais inesperado, a gratidão de um convalescente - pois a convalescença era esse inesperado. "Gaia ciência": ou seja, as saturnais de um espírito que pacientemente resistiu a uma longa, terrível pressão - pacientemente, severa e friamente, sem sujeitarse, mas sem ter esperança -, e que repentinamente é acometido pela esperança, pela esperança de saúde, pela embriaguez da convalescença. [...] Todo este livro não é senão divertimento após demorada privação e impotência, o júbilo da força que retorna, da renascida fé num amanhã, do repentino sentimento e pressentimento de um futuro, de aventuras próximas, de mares novamente abertos, de metas novamente admitidas, novamente acreditadas. (FW/GC, prólogo, 1, KSA 3.345).

Essa citação parece revelar o mais íntimo de seu autor. Nela nosso filósofo fala com toda propriedade acerca do que quer expressar. Discorre irretocavelmente acerca da experiência (Erfahrung) de sua convalecença, faz de sua vivência (Erlebnis) mais amarga um experimento (Versuch) consigo. Nietzsche explora toda sua riqueza literária para colocar em palavras do modo mais filosófico e expressivo uma singularidade pela qual passou e da qual se apropriou como a vivência mais sua. Assim, esta se trata de uma citação que nos leva diretamente a um tema que consideramos de bastante importância para a apreciação, em sua devida altura, da filosofia nietzschiana. $\mathrm{O}$ que nos parece é que a filosofia do nosso pensador é uma filosofia visceral, repleta de sentimentos arrebatadores. Em suma, Nietzsche parece filosofar a partir de sua vivência e fazer questão de pensar a partir de uma filosofia de sua vivência sem descurar, contudo, de que seja apenas uma vivência, uma perspectiva dentre todas as demais, mas sobretudo, considerando que "[...] desde que se é uma pessoa, tem-se necessariamente a filosofia de sua pessoa [...]" (FW/ GC, prólogo, 2, KSA 3.347). 
Adami, J. D.

Para uma discussão mais pormenorizada a respeito do termo Erlebnis, vale conferir o artigo intitulado $O$ Conceito de Vivência (Erlebnis) em Nietzsche: Gênese, Significado e Recepção (Viesenteiner, 2013), no qual o autor faz, dentre outras coisas, uma análise histórica do termo. No referido artigo o autor explicita a tríplice significação de vivência (Erlebnis) que consiste em imediatidez (Unmittelbarkeit), significabilidade (Bedeutsamkeit) e incomensurabilidade (Inkommensurabilität). Por imediatez, devemos entender que uma vivência, evidentemente, precisa ser presenciada, ser vivida, ou seja, uma experiência que se tem acerca do mundo estando no mundo, presentificado nele; por significablilidade, entende-se que a vivência precisa ter um impacto naquele que a vivencia de modo a afetá-lo de modo global, isto é, precisa ter um sentido para aquele que a vivencia e com isso ser dotada de significado; a incomensurabilidade se refere ao caráter estético da vivência, que não pode ser avaliado por convenções ou padrões morais e que está para além da própria razão. O termo Erlebnis é utilizado frequentemente por Nietzsche, mas, como Visenteiner aponta, não de modo sistematizado. Por vezes Nietzsche o substitui pelo termo Erfahrung (experiência) ou Versuch (experimento). No artigo intitulado Erlebnis (vivência): autobiografia ou autogenealogia? Sobre a "crítica da "razão da minha vida" em Nietzsche (Viesenteiner, 2010), o autor também explora, embora de modo mais breve, a tríplice significação do termo Erlebnis e se utiliza da análise do termo para fundamentar que, não obstante Nietzsche escreva sobre sua vivência filosófica, sua filosofia não é necessariamente autobiográfica.

Não estamos seduzidos por esta hipótese, haja vista entendermos que a vivência de Nietzsche é das mais filosóficas, tornando impossível dissociar sua filosofia de sua vivência (Erlebnis) e de sua vida. Contudo, quase desnecessário apontar, a proposta nietzschiana passa ao largo de uma proposta autobiográfica descritiva de suas experiências. Nietzsche traduz em termos filosóficos o que vivenciou

$56 \mid$ Cad. Nietzsche, Guarulhos/Porto Seguro, v.40, n.2, p. 52-73, maio/agosto, 2019. 
na singularidade de suas experiências ou, dito de outro modo, deixou como legado apenas o que há de filosófico em suas vivências, ou seja, ele nos deixou suas vivências e seria tautologia adjetivá-las de filosóficas, pois, como já afirmado, a vivência de Nietzsche é filosófica, nos termos do que ele entende por filosofia - da destruição à criação de valores, da saúde à doença, do declínio à superação, da análise da metafísica moral escrava à afirmação da moral da grande saúde. A tudo isto vivenciou, não apenas viveu. $\mathrm{E}$ por vivenciar queremos dizer que viveu de modo crítico, escavando os preconceitos morais e valores intrínsecos àquilo com o que teve contato. Numa vivência filosófica, isto não deixa de ser autobiográfico e embora não se atenha a meras descrições vivenciais, diz-nos muito sobre seu autor e sua vida. O lado mais íntimo e profundo, o qual nenhuma biografia ou autobiografia descritiva galgaria alguma vez alcançar está desvelado nos escritos nietzschianos.

Concordamos com Viesenteiner quando ele sugere que se trata de uma autogenealogia, pois os escritos nietzschianos são as marcas da constituição de seu Eu mais próprio, seu Si-mesmo (Selbst). Contudo, isso não descaracteriza o teor biográfico de seus escritos. A nosso ver é sim uma super-autobiografia, no sentido de uma grande autobiografia. A filosofia nietzschiana nos mostra o filósofo na mais introspectiva análise de si e do que o cerca. Não há clara distinção em Nietzsche acerca do Si e do entorno, desse modo, seu pensamento e análise da cultura, dos valores e tudo o mais, está diretamente atrelado ao seu Si-mesmo (Selbst) - é a expressão deste Si-mesmo. Viesenteiner gostaria de justificar sua tese apegando-se à famosa frase: "Uma coisa sou eu, outra são meus escritos" (EH/EH, Por que escrevo tão bons livros, 1, KSA 6.298). Contudo, o ponto principal abordado por Nietzsche nessa passagem pareceu-nos ser ignorado. Este ponto é dito já na frase seguinte da referida citação: "Uma coisa sou eu, outra são meus escritos. Abordarei, antes de falar deles, a questão de serem compreendidos ou incompreendidos. Faço-o com a 
Adami, J. D.

negligência mais apropriada: pois este não é ainda o tempo para essa questão. Tampouco é ainda o meu tempo, alguns nascem póstumos." (EH/EH, Por que escrevo tão bons livros, 1, KSA 6.298).

Não nos parece lícito aceitar que Nietzsche esteja endossando uma atitude ambígua em seus escritos. Não nos parece, em absoluto, que ele escreva algo e que aquilo possa não lhe dizer respeito ou ser distinto dele, como a interpretação viesenteineriana da referida passagem o sugere. A célebre frase trata, a rigor, primeiramente da má interpretação que amiúde era feita dos escritos nietzschianos; e, corolariamente, da má imagem que se fazia da figura do filósofo: "Não sou, por exemplo, nenhum bicho-papão, nenhum monstro moral [...]" (EH/EH, Prólogo, 2, KSA 6.257). Nietzsche propôs-se a investigar o valor dos valores vigentes de sua época, mas não o fez com intenções perversas, muito pelo contrário. Quem percorre seus escritos percebe subrepticiamente o amor à vida e à promulgação da existência. Mas quem compreenderia esse incompreendido? "Quem acreditou haver compreendido algo de mim, havia me refeito como algo à sua imagem - não raro um oposto de mim, um 'idealista', por exemplo; quem nada havia compreendido de mim, negou que eu tivesse de ser considerado." (EH/EH, Por que escrevo tão bons livros, 1, KSA 6.298). Essa é mais uma citação da referida passagem, na qual Nietzsche, supostamente, se distingue de seus escritos. Mas ele faz tal afirmação porque de fato é distinto daquilo que escreve ou porque seus escritos são, amiúde, tomados e interpretados de modo muito distinto daquilo que se propõem a ser?

Figura-nos, cada vez mais, que aquela frase que parece impor uma ambiguidade em Nietzsche e sugerir uma dissociação na disposição dos impulsos do fllósofo é, tão somente, apenas mais uma incompreensão. Tal equívoco é bem explicado pelo próprio Nietzsche ainda na mesma passagem: "Em última instância, ninguém pode escutar mais das coisas, livros incluídos, do que aquilo que já sabe." (EH/EH, Por que escrevo tão bons livros, 1, KSA 6.298).

58 | Cad. Nietzsche, Guarulhos/Porto Seguro, v.40, n.2, p. 52-73, maio/agosto, 2019. 
Isto é, novamente Nietzsche parece apontar para o sentimento de incompreensão de seus escritos. Não nos surpreende que um pensador com concepções tão singulares e insuspeitadas, como é o caso de Nietzsche, tenha fomentado todo tipo de incompreensões; não por falha de seu pensamento ou escrita. Um bom escritor necessita de um intérprete que alcance, o máximo que possa, sua altura.

Assim, parece-nos translúcido que quando Nietzsche afirma: "Uma coisa sou eu, outra são meus escritos." (EH/EH, Por que escrevo tão bons livros, 1, KSA 6.298), ele está se referindo precisamente à incompreensão que grassa na leitura de seus pensamentos e à distorcida imagem que fazem de sua figura: "Prevendo que dentro de pouco tempo devo dirigir-me à humanidade com a mais séria exigência que jamais lhe foi colocada, parece-me indispensável dizer quem sou. Na verdade já se deveria sabê-lo, pois não deixei de "dar testemunho’ de mim.” (EH/EH, Prólogo, 1, KSA 6.257).

Ainda neste seara, escreve Nietzsche em Além do Bem e do Mal: "Gradualmente foi se revelando para mim o que toda grande filosofia foi até o momento: a confissão pessoal de seu autor, uma espécie de memórias involuntárias e inadvertidas; e também se tornou claro que as intenções morais (ou imorais) de toda filosofia constituíram sempre o germe a partir do qual cresceu a planta inteira." (JGB/BM I, 6, KSA 5.19).

Retornando ao prólogo de A Gaia Ciência supracitado: seria lícito perguntar, ainda que timidamente, qual seria o germe que subjazeria à filosofia do nosso pensador naquele momento efusivo de jubilosa convalescença e que teria dado origem àquela estirpe de pensamentos primaveris? Teria sido um germe da superação ou da decadência? ${ }^{4}$ A este respeito trazemos a seguinte citação:

4 "Quanto aos valores artísticos todos, utilizo-me agora dessa distinção principal: pergunto, em cada caso, ‘foi a fome ou a abundância que aí se fez criadora?'.” (FW/GC V, 370, KSA 3.619). Trata-se de um aforismo do quinto livro de $A$ Gaia Ciência; de um período mais tardio da filosofia nietzschiana, portanto. Nietzsche parece, com isso, estabelecer um critério avaliador dos valores artísticos; e não há razões para não estendermos este critério à sua forma de avaliar os pensamentos filosóficos. 
Adami, J. D.

Não, a vida não me desiludiu! A cada ano que passa eu a sinto mais verdadeira, mais desejável e misteriosa - desde aquele dia em que veio a mim o grande libertador, o pensamento de que a vida poderia ser uma experiência de quem busca conhecer - e não um dever, uma fatalidade, uma trapaça! - E o conhecimento mesmo: para outros pode ser outra coisa, um leito de repouso, por exemplo, ou a via para esse leito, ou uma distração, ou um ócio - para mim ele é um mundo de perigos e vitórias, no qual também os sentimentos heroicos têm seus locais de dança e de jogos. "A vida como meio de conhecimento" - com este princípio no coração pode-se não apenas viver valentemente, mas até viver e rir alegremente! (FW/GC IV, 324, KSA 3.552).

A vida mesma como fonte de conhecimento. Talvez se consolide com esta ideia a proposta nietzschiana que gostaríamos de chamar de filosofia como vivência. Uma filosofia que extrai de tudo que se é elementos para construção de sua visão de mundo ${ }^{\mathbf{5}}$. Interessante pontuar que a visão de mundo que parece sustentar a concepção filosófica nietzschiana, sobretudo nesse momento tão delicado de sua vida/pensamento que concerne ao período da redação d'A Gaia Ciência, é justamente aquela da plenitude e da força. Nietzsche aceita de bom grado todo seu sofrimento e aprende com ele, o vivencia e filosofa a partir dele. A partir do que o destino lhe colocou, ele constrói a filosofia que lhe é singular. Isso parece nos remeter ao caráter afirmador da filosofia nietzschiana, a qual jamais estará emaranhada a lamentações inócuas.

Nietzsche, ao que nos parece, jamais sucumbiria a uma filosofia da negação daquilo que é ou que foi. Pode sim lançar críticas e cicatrizes ferozes à sua volta, mas sempre lidando com circunstâncias reais, com plena consciência de que não se muda o que se passou, no máximo se tem olhos diferentes para o que se cristalizou pela ampulheta do tempo. Jamais será lícito, na visão de

5 Pela expressão "tudo que se é", entenda-se a disposição e dinâmica de forças atuantes num organismo. Por "organismo" entenda-se a representação de uma unidade. Por "unidade" entenda-se uma disposição de forças que adquiriu certa preponderância e direção na dinâmica da luta por potenciação.

$60 \mid$ Cad. Nietzsche, Guarulhos/Porto Seguro, v.40, n.2, p. 52-73, maio/agosto, 2019. 
mundo nietzschiana, fazer abstrações acerca de como o mundo seria se determinados eventos não houvessem ocorrido, ou ocorressem de modo diferente. Incorrer em tais fantasias seria um pulo na idealidade e uma negação do mundo que incessantemente vem a ser, isto é, do único mundo. Assim, seria um grande contrassenso uma filosofia que sempre se comportou de modo afirmativo ter seu mentor entregue a lamentações acerca de sua terrível enfermidade.

Uma vez tendo percebido a enfermidade inerente à moral do romantismo alemão, Nietzsche finalmente percebeu também a enfermidade a que seu espírito estava sujeito. E, nesse caso, a aguda consciência de si, fez com que seu espírito expurgasse a intoxicação de uma ideologia que aviltava sorrateiramente a potência afirmadora de nosso pensador.

Contudo, talvez não estejamos equivocados em dizer que Nietzsche tentou vivenciar de modo afirmativo o romantismo alemão. O Nascimento da Tragédia, não obstante seu romantismo e idealismo, mantém uma forte índole afirmativa e parece se locomover no terremo do romantismo por desaviso, como um estrangeiro que passeia pela mata sem saber que circunda um pântano de areia movediça e que tem os pés tão ligeiros e leves que está como que imune a sucumbir ao ardiloso solo em que pisa.

Muito embora Nietzsche pareça ter de fato se deixado seduzir por idealizações metafísicas, o pensamento intrínseco a $O$ Nascimento da Tragédia é um pensamento dinâmico, dionisíaco, destrutivo, na mesma medida em que é criador - numa palavra: afirmador. Não impera ali a moral decadente da busca pela paz e estagnação, mas antes uma busca incessante pela riqueza de formas a eclodir no mundo fenomênico.

O idealismo, por sua vez, busca um outro mundo por não suportar o mundo na terribilidade de seu devir, ao passo que a filosofia do jovem Nietzsche parece criar um mundo suprassensível pleno em contradições e que luta por manifestar-se em formas; isto 
Adami, J. D.

é, um mundo ainda mais terrível do que o mundo fenomênico, já sobremaneira insuportável aos idealistas. Nesse sentido, Nietzsche era um contra-idealista insciente idealizando um mundo por excesso de força e não por falta, por fome; como se nos parece que os idealistas e sua moral decadente o fazem. Contudo, nosso filósofo sucumbiu à enfermidade ao perceber que fortalecia um movimento que era contrário ao que lhe era mais íntimo, sua potência afirmadora.

Escreve Nietzsche: "Para ser justo com $O$ nascimento $d a$ tragédia (1872), será preciso esquecer algumas coisas. Ele influiu, e mesmo fascinou, pelo que nele era erro - por sua aplicação ao wagnerismo, como se este fosse um sintoma de ascenção." (EH/EH, O Nascimento da Tragédia, 1, KSA 6.309). Trata-se, a nosso ver, portanto, de uma obra deslocada. Um livro de afirmação e aceitação da existência em toda sua terribilidade a serviço de uma ideologia da negação, que foge justamente de toda terribilidade.

O jovem Nietzsche, ante a necessidade de escapar de tal movediço fundamento que tende a engolir tornando louco-insensível ou alienado-obtuso quem nele se sustente por muito tempo, impôs a si, durante a redação de Humano, Demasiado Humano, o rigoroso método científico como um expectorante que lhe purificasse de tão venenosos ares. Após isso, em seu momento de convalescença no qual se consolida a sua gaia obra, finalmente ele se vê novamente em condições de alçar-se para além de sua rigorosa, amarga e acre dieta. Mas com isso não estaria ele incorrendo novamente no erro de lançar-se ao mundo das fantasias e idealidades? Não sucumbiria nosso filósofo novamente ao mundo onírico da metafísica ao desregrarse de sua dieta espiritual? Quando ele fala da rangente máquina da razão ${ }^{6}$ e de como o pensamento alegre, fluido e célere lhe parece o mais apreciável, não estaria justamente abandonando sua nova conquista em terras da mais firme imanência, longe de todo reino de transcendência metafísica? Estaria nosso filósofo se abandonando ao

6Cf. FW/GC IV, 327, KSA 3.555.

62 | Cad. Nietzsche, Guarulhos/Porto Seguro, v.40, n.2, p. 52-73, maio/agosto, 2019. 
reino das confabulações, afrouxando as rédeas da razão? Não seriam justamente o rigor e a intrepidez da ciência que impediriam que se perdesse o bom senso em questões filosóficas mantendo amordaçada a necessidade metafísica, ela, que deveria ser solta somente para o aquecimento de um espírito que se enregelhou demais pela aridez desértico-noturna científica? O que pretende Nietzsche!? que o sistema superaqueça, contrabalançando o intenso inverno ao qual sua alma foi submetida nos tempos de enfermidade? Vejamos o seguinte aforismo presente na obra Humano, Demasiado, Humano:

Com o enorme aceleramento da vida, o espírito e o olhar se acostumam a ver e julgar parcial ou erradamente, e cada qual semelha o viajante que conhece terras e povos pela janela do trem. Uma atitude independente e cautelosa no conhecimento é vista quase como uma espécie de loucura, o espírito livre é difamado, particularmente pelos eruditos, [...] que de bom grado o baniriam para um solitário canto da ciência [...]. Uma lamentação como a que acaba de ser entoada provavelmente terá o seu tempo e se calará por si mesma, ante um intenso retorno do gênio da meditação (MA I/HH I 282, KSA 2.231)

Este gênio da meditação parece ser exatamente a caricatura do intelecto rangente, que se movimenta com dificuldade, que pensa com siso e sem riso, que funciona mediante grande esforço e rígida disciplina. A gaia ciência parece consistir num pathos bem oposto a isso. Mas seria um pathos irrazoável? Vejamos:

Há uma honestidade que sempre faltou aos fundadores de religiões e pessoas desse tipo: - eles nunca fizeram de suas vivências [Erlebnissen] uma questão de consciência para o conhecimento. "O que foi que vivi realmente? Que sucedeu então em mim e à minha volta? Minha razão estava suficientemente clara? Minha vontade estava alerta para todos os enganos dos sentidos e foi valorosa ao defender-se das fantasias?" - nenhum deles fez estas perguntas, nem as caras pessoas religiosas as fazem ainda hoje: elas têm, isto sim, sede de coisas contrárias à razão, e não querem tornar muito difícil a satisfação de tal sede - desse modo, vivenciam "milagres" e "renascimentos" e escutam vozes de anjos! Mas nós, os sequiosos de razão, 
Adami, J. D.

queremos examinar nossas vivências [Erlebnissen] do modo rigoroso como se faz uma experiência [Versuch] científica, hora a hora e dia a dia! Queremos ser nossos experimentos [Experimente] e nossas cobaias [Versuchs-Thiere]. (FW/GC IV, 319, KSA 3.550, grifo nosso).

Numa mesma obra, a saber A Gaia Ciência, Nietzsche parece tecer críticas e apologias à razão. Como podemos compreender que ele critique a máquina rangente da razão almejando se colocar acima da racionalidade e, ao mesmo tempo, se defina como "nós, os sequiosos de razão"? Seria esse um titubear do passo convalescente de Nietzsche? Até que ponto essa ciência gaia despoja-se, de fato, de uma razão? E ainda, não deixaria ela de ser gaia ao se enquadrar nos limites da razão; não perderia sua leveza e fluidez ao curvar-se em racionalidade meditativa? Vejamos o que escreve Nietzsche:

O nosso ar. - Nós bem sabemos que, para quem lança um olhar à ciência como que de passagem, à maneira das mulheres e, infelizmente, de muitos $\operatorname{artistas}^{7}$ o rigor que pede o seu serviço, a inflexibilidade nas pequenas como nas grandes coisas, a rapidez em ponderar, julgar, condenar, têm algo que infunde temor e dá vertigem. Assusta, particularmente, o fato de aí se requerer o mais difícil e se fazer o melhor possível, sem que louvor e distinções sejam ouvidos, mas apenas censuras e admoestações, como entre soldados - pois o bem feito é tido como norma, o fracasso, como exceção; e a norma, como sempre, guarda silêncio. Com este "rigor da ciência" dá-se o mesmo que com a forma e a cortesia da melhor sociedade: - ele assusta os não-iniciados. Mas quem a ele se habitua talvez não consiga viver senão nesse ar claro, transparente, vigoroso e bastante elétrico, nesse ar viril. Nenhum outro lugar lhe será suficientemente puro e arejado: [...] Mas nesse elemento claro e severo ele tem toda a sua energia: aí ele pode voar! Por que tornaria ele a descer àquelas águas turvas, onde temos que nadar e patinhar e perdemos a cor das asas? - Não! Para nós é muito difícil viver ali: que fazer, se nascemos para o ar, o ar puro, nós, rivais dos raios de luz, e se bem gostaríamos, como eles, de andar sobre partículas do éter,

7 Acerca do tom eminentemente machista da frase, válido pontuar que nosso autor parece utilizar a imagem feminina de sua época como selo da frivolidade e fraqueza de personalidade, assim como o faz para os artistas de seu tempo, opondo-os ao rigor e intrepidez da ciência.

64| Cad. Nietzsche, Guarulhos/Porto Seguro, v.40, n.2, p. 52-73, maio/agosto, 2019. 
e não fugindo, mas rumando para o Sol! Mas isso não podemos fazer: então façamos o que somente nós conseguimos: trazer luz à Terra, ser "a luz da Terra"! E para isso temos nossas asas e nossa rapidez e rigor, por isso somos viris e mesmo terríveis, como o fogo. Que nos temam aqueles que não souberem aquecer-se e iluminar-se junto a nós! (FW/GC IV, 293, KSA 3.533, grifo nosso).

Nesta passagem podemos vislumbrar a força que Nietzsche impele à sua ciência gaia, etérea, flamejante e voadora; que é rápida sem perder o rigor e vigorosa em seu vôo de leveza ágil; que de suas caraterísticas mais próprias obtém ainda mais energia para assim continuar sendo. Parece-nos que foram precisos ajustes até que se chegasse a uma concepção com uma afinação tão libertadora. Por muito tempo precisou-se do gênio meditativo, esculpindo sua corcunda, até que pudesse ver-se livre de concepções calcificantes que o tornavam pesado e imóvel.

Talvez algumas respostas às questões levantadas acerca desta divergência a respeito da racionalidade - ora lenta e meditativa, ora rápida e intuitiva - estejam no próprio parágrafo 319 (KSA 3.550), com o qual iniciamos a polêmica acerca da concepção de razão presente n'A Gaia Ciência. No referido parágrafo, Nietzsche escreve sobre fazer de sua vivência "uma questão de consciência para o conhecimento". Filosofia como vivência. Talvez somente essa concepção explique a riqueza e dinâmica dos pensamentos nietzschianos. Eles não se prendem a uma teoria lógico-formal, a um sistema conceitual que almeja a estabilidade. Antes, a mudança parece ser selo de sua filosofia. Não uma mudança aleatorizada e inconsequente de suas concepções filosóficas, mas uma mudança de depuração e contínua superação confluindo cada vez mais na direção de impulsos afirmadores. A concepção da racionalidade em Nietzsche é tão multifária quanto o são as suas vivências e experiências com a razão. 
Adami, J. D.

Na supracitada passagem (FW/G IV, 293, KSA 3.533), é evidente o teor leve e celére da razão. A razão ali representada pelo espírito científico é comparada à leveza e pureza do ar, bem como ao calor e rapidez da própria luz solar; e numa mesma obra fala-se da razão rangente, pesada, obscura? ${ }^{\mathbf{8}}$. Em Humano, Demasiado Humano fala-se da aridez e resfriamento das ciências e sua racionalidade. Mas agora, nesta altura, em sua gaia manifestação, ela é quente, iluminada, arejada, leve. E, se em momentos anteriores precisavase da arte para que a ciência não nos sufocasse ${ }^{9}$ e a ela o espírito livre se submetia com certa vergonha e remorso, agora já não se pode mais viver sem ela e sua leveza, parece tratar-se de algo mais pleno. Podemos suspeitar de que Nietzsche esteja, nesse momento, se referindo à ciência e à razão sob um novo enfoque, dado que passam a ser vistas pelo pensador como céleres, leves e solares. Teria ele alcançado uma nova concepção acerca de tais assuntos? E quando ele menciona sobre descer às águas turvas, estaria se referindo aos saberes e fantasias metafísicos, ou àquela ciência e razão áridas e gélidas? Fortuitamente Nietzsche escreveu uma passagem que pode vir em nosso socorro e ajudar em algumas dúvidas:

Contra os caluniadores da natureza. - São para mim desagradáveis as pessoas nas quais todo pendor natural se transforma em doença, em algo deformante e ignominioso - elas nos induziram a crer que os pendores e impulsos do ser humano são maus; elas são a causa de nossa grande injustiça para com nossa natureza, para com toda natureza! Há pessoas bastantes que podem se entregar a seus impulsos com graça e despreocupação: mas não o fazem, por medo dessa imaginária "má essência" da natureza! Vem daí que se ache tão pouca nobreza entre os homens; pois a marca desta sempre será não temer a si próprio, nada esperar de vergonhoso de si próprio, não hesitar em voar para onde somos impelidos - nós, pássaros

8 Cf. FW/GC IV, 327, KSA 3.555.

9 Estamos, de fato, associando fortemente ciência e razão. Entendemos que o rigor do método científico pressupõe o uso da razão. A questão aqui é descobrir a que tipo de razão Nietzsche está se referindo em cada caso.

$66 \mid$ Cad. Nietzsche, Guarulhos/Porto Seguro, v.40, n.2, p. 52-73, maio/agosto, 2019. 
nascidos livres! Aonde quer que cheguemos, tudo será livre e ensolarado à nossa volta. (FW/GC IV, 294, KSA 3.534, grifo nosso).

Cada vez mais A Gaia Ciência nos parece um livro solar, livre, leve/rápido e claro. Tomando por base essa passagem, estaríamos sendo ousados em demasia ao conceber que o espírito meditativo descrito anteriormente por Nietzsche, em sua diligente e lenta atividade, semelharia àquele ranger de engrenagens enferrujadas descrito no páragrafo 327 de A Gaia Ciência (FW/GC 327, KSA $3.555)$, que se movem com cautela e medo de destroçarem a si mesmas a cada instante que se passa? Talvez seja assim, talvez não estejamos tão equivocados em pensar que o espírito meditativo luta contra si mesmo, hesita diante de seu eu mais próprio, ${ }^{10}$ falseia o passo a que lhe impelem seus instintos. Uma natureza gaia se move confiante, é rápida porque fia-se nos seus mais céleres instintos e sabe que lhe levarão ao destino que sua natureza mais íntima almeja, ou, ao menos, farão o possível para isso. Uma natureza assim deixa-se levar e frui mais da vida, sem, contudo, perder-se ante a fantasias metafísicas; somente um instinto decadente o faria, um instinto romântico e idealista em demasia!

Talvez seja hora de nos perguntarmos novamente por qual razão Nietzsche prescreveu deliberadamente para si, aquela dieta acre, amarga e dolorosa, que, ao que nos parece, foi imposta durante a redação de Humano, Demasiado Humano. Quem infligiria todo esse sofirmento a si mesmo e com aguda consciência? Somente alguém que precisasse, por questões de saúde, reorganizar e regular seus próprios instintos que se tornaram doentios e, justamente por isso, levaram ao adoecimento! - Mas vejam, não houve também um impulso em prescrever para si uma tal dieta?

10 Onde escreveu-se "de seu eu mais próprio", entenda-se: da direção preponderante de suas disposições de força. 
Adami, J. D.

Desse modo, a cautela do espírito meditativo foi o efeito colateral e inevitável de um organismo que busca novamente a convalescença e a saúde. Parte do sistema estava contra si e o movimento não poderia deixar de ser exercido senão com muita dificuldade e ranger de engrenagens, pois muitas forças antagônicas tensionavam toda a máquina. Um tal intelecto doentio é rangente, seu sistema não está integrado, as forças se dissipam.

Interessante notar que, ao que parece, o adoecimento se implantou na medida em que alterou sua direção. Tivesse Nietzsche aceitado e se entregado aos devaneios metafísicos de sua juventude, sua máquina não rangeria, pelo contrário, mover-se-ia celeremente para fora do mundo, distante em idealidades. Humano, Demasiado Humano foi o antídoto para o que havia de idealista e romântico no pensamento nietzschiano da juventude. A Gaia Ciência, ao que quer nos parecer, marca a superação dessa enfermidade, o fim da dieta e do verdugo e acre tratamento; grava na história do pensamento nietzschiano uma era na qual se pode, de fato, confiar em seus instintos novamente, onde todos eles estão voltados para a vida e para o mundo, o único mundo. Um restabelecimento desses é conseguido a duras penas, é forjada na luta contra si, contra o que há de decadente em si, em prol daquilo que nos coloca em posição de agir no mundo e não para fora dele. Somente assim Nietzsche parece ter alcançado a grande saúde, como ele a chama. Mas essa grande saúde sempre se está em iminência de perdê-la, pois só assim se vivencia aquilo que a existência é em sua plenitude, só assim se tira o máximo da vida ${ }^{11}$. A grande saúde. - Nós, os novos, sem nome, de difícil compreensão, nós, rebentos prematuros de um futuro ainda não provado, nós necessitamos, para um novo fim, também de um novo meio, ou seja, de uma nova saúde, mais forte alerta alegre firme

11 “ ‘[... Eu sei mais sobre a vida, porque frequentemente estive a ponto de perdê-la; e justamente por isso obtenho mais da vida do que todos vocês.' " (FW/GC IV, 303, KSA 3.541). O valor à vida é dado na mesma medida que se reconhece sua finitude e fugacidade. E daquilo o qual sabemos valoroso, dele fruiremos com maior júbilo.

68 | Cad. Nietzsche, Guarulhos/Porto Seguro, v.40, n.2, p. 52-73, maio/agosto, 2019. 
audaz que todas as saúdes até agora. Aquele cuja alma anseia ter experimentado o inteiro compasso dos valores e desejos até hoje existentes e haver navegado as praias todas desse "Mediterrâneo" ideal, aquele que quer, mediante as aventuras da vivência [Erfahrung] mais sua, saber como sente um descobridor e conquistador do ideal, e também um artista, um santo, um legislador, um sábio, um erudito, um devoto, um adivinho, um divino excêntrico de outrora: para isso necessita mais e antes de tudo uma coisa, a grande saúde - uma tal que não apenas se tem, mas constantemente se adquire e é preciso adquirir, pois sempre de novo se abandona e é preciso abandonar... (FW/GC V, 382, KSA 3.635, grifo nosso). ${ }^{12}$

Novamente surge o tema da filosofia como vivência e de como é preciso de uma grande saúde, de uma verdadeira saúde, para que se possa ousar viver de modo mais amplo e intenso a filosofia que se tem - a filosofia mais sua, tal como a vivência mais sua. Gaia ciência quer se referir também, conforme nos parece, ao movimento em direção à grande saúde. Ela é o pathos, por excelência, do sistema ou organismo que se move de modo célere, fácil e alegre. Mas e quanto à razão rangente? Foi ela superada? A esse respeito é de grande valor uma passagem da obra Assim Falou Zaratustra:

O corpo é uma grande razão, uma multiplicidade com um só sentido, uma guerra e uma paz, um rebanho e um pastor.

12 "Enfim, permaneceria aberta a grande questão de saber se podemos prescindir da doença, até para o desenvolvimento de nossa virtude, e se a nossa avidez de conhecimento e autoconhecimento não necessitaria tanto da alma doente quanto da sadia; em suma, se a exclusiva vontade de saúde não seria um preconceito, uma covardia e talvez um quê de refinado barbarismo e retrocesso." (FW/GC III, 120, KSA 3.477). Só se pode saber o que é saúde ao experimentar também enfermidade, é assim que as coisas se nos tornam verdadeiramente conhecidas: pela diferença. A constância eterna é vizinha à insciência. Aquilo que é habitual e perene passa ignorado, desconhecido, imanifesto. Quem conhece melhor da vida do que a morte? E quem conhece mais da saúde? A filosofia nietzschiana é a das vivências, busca conhecimento na raiz do que somos mais do que nos livros e teorias idealistas. Uma filosofia assim tem de passar por toda amplitude de espectros dos sentimentos, da saúde à doença; sentir todos os valores, olhar sob os mais diversos olhos na mais íntima peculiaridade e capricho de seu interpretar - a riqueza infinita do existir. 
Adami, J. D.

Instrumento de teu corpo é também tua pequena razão que chamas de "espírito", meu irmão, um pequeno instrumento e brinquedo de tua grande razão.

"Eu", dizes tu, e tens orgulho dessa palavra. A coisa maior, porém, em que não queres crer - é teu corpo e sua grande razão: essa não diz Eu, mas faz Eu. [...]

Por trás dos teus sentimentos e pensamentos, irmão, há um poderoso soberano, um sábio desconhecido - ele se chama Si-mesmo [Selbst]. Em teu corpo habita ele, teu corpo é ele.

Há mais razão em teu corpo do que em tua melhor sabedoria. E quem sabe por que teu corpo necessita justamente de sua melhor sabedoria? (Za/ZA I, Dos desprezadores do corpo, KSA 4.39, grifo nosso).

Estaríamos sendo ousados demais ao afirmar que a grande razão nietzschiana é superior a toda sabedoria e toda pequena razão, justamente por ela ser a maior sabedoria, justamente por ela, sempre $e$ reiteradamente, restaurar a grande saúde? Parece-nos essa a natureza dessa razão/sabedoria que aparece em alguns pontos da obra $A$ Gaia Ciência. Parece tratar-se de uma grande razão, uma razão que emerge de um corpo saudável, ${ }^{13}$ que finalmente recuperou sua saúde e pode fiar-se em seus instintos.

É preciso atentar para o equívoco de que Nietzsche almeja a pequena saúde, que seria a mera saúde física. A grande saúde, quer nos parecer, abarca inclusive os estados de enfermidade. Arriscaríamos dizer que a grande saúde impele o homem de conhecimento ao conhecimento, tanto quanto impeliria o guerreiro à guerra, por mais que isto pudesse lhe custar a vida e todas as vindouras possibilidades de participar de novas batalhas. Vimos que, para Nietzsche, a transição pela enfermidade constitui meio de conhecimento. Assim, uma grande saúde parece ser aquela boa administração dos instintos, mais do que o bem-estar físico. Uma

13 Deve-se compreender que a noção de corpo em Nietzsche não remete à materialidade. 0 corpo é a manifestação das disposições de forças atuantes organizadas numa representação de unidade. Em outras palavras, corpo não é material, não implica em unidade, tampouco se refere ao estabelecimento de um sujeito ou substrato metafísico.

$70 \mid$ Cad. Nietzsche, Guarulhos/Porto Seguro, v.40, n.2, p. 52-73, maio/agosto, 2019. 
grande saúde não é necessariamente aquela que impede a queda na enfermidade, isso seria uma limitação imperdoável no legítimo homem de conhecimento nietzschiano. A grande saúde é, antes, aquela que sempre e reiteradamente permite o restabelecimento. É um impulso que mesmo em meio às piores condições aponta para a superação e intensificação de potência. Escreve o filósofo: “[...] odeio os hábitos duradouros, penso que um tirano se me avizinha e que meu ar fica espesso, quando os eventos se configuram de maneira tal que hábitos duradouros parecem necessariamente resultar deles: por exemplo, devido a um emprego, ao trato constante com as mesmas pessoas, a uma morada fixa, uma saúde única." (FW/GC IV, 295, KSA 3.535, grifo nosso). Isto é, quanto mais ampla a vivência, mais vasta a filosofia que se pode fazer a partir dela.

Nietzsche parece referir-se a um corpo próprio em sua singularidade, que manifesta seu Si-mesmo (Selbst), sua mais profunda ânsia pela vida - pois em suma, para Nietzsche, é isto que um organismo é, uma busca pela intensificação de potência, ele é a manifestação do puro fluir da vida. ${ }^{14} \mathrm{~A}$ grande razão faz Eu na medida em que é auto-afirmadora, na medida em que confia sem receio em seus instintos que são, no fundo, sua grande razão; na medida em que cria o seu entorno, seu contexto e seus sentidos e, por vezes, seus valores. Esta forma de razão parece-nos, sim, compatível com uma gaia sabedoria que se movimenta fluidicamente, espontaneamente, solarmente alegre, aereamente leve. Ela comanda a multiplicidade do corpo em um só sentido, não tem o coração contra si. $\mathrm{O}$ organismo todo está integrado e é um meio viável para se conduzir pela existência, para vivenciar-se e, no caso de Nietzsche, construir sua singular filosofia da vivência (Erlebnis) e da afirmação.

14 "[...] o que quer cada uma das minúsculas partes de um organismo vivo é um plus de potência." (Nachlass/FP, 1888, 14[174], KSA 13.360). 
Adami, J. D.

\section{Great Health and Philosophy as Personal Experience}

Abstract: To approach living and self creation exploring their relations will be one of the objectives of this paper, as well as to elucidate the human capacity to give meaning to their experiences, which is also an artistic attitude towards existence it self.

Keywords: The gaia Science, living, great health, art.

\section{Referências Bibliográficas}

NIETZSCHE, F. W. Die Fröhlich Wissenchaft: "lagayascienza". Leipzig, 1887. Disponível em: <http://www.nietzschesource.org/\#eKGWB/FW>. Acesso em 17 de maio de 2016.

NIETZSCHE, F. W. O Nascimento da Tragédia: ou Helenismo e pessimismo. Tradução, notas e posfácio de J. Guinsburg. São Paulo: Companhia das Letras, 1992.

NIETZSCHE, F. W. Humano, Demasiado Humano: Um livro para espíritos livres. Tradução, notas e posfácio de Paulo César de Souza. São Paulo: Companhia das Letras, 2000.

NIETZSCHE, F. W. A Gaia Ciência. Tradução, notas e posfácio de Paulo César de Souza. São Paulo: Companhia das Letras, 2001.

NIETZSCHE, F. W. Além do Bem e do Mal: prelúdio a uma filosofia do futuro. Tradução, notas e posfácio de Paulo César de Souza. São Paulo: Companhia das Letras, 2005.

NIETZSCHE, F. W. Ecce Homo: Como alguém se torna o que é. Tradução, notas e posfácio de Paulo César de Souza. São Paulo: Companhia das Letras, 2008.

72 | Cad. Nietzsche, Guarulhos/Porto Seguro, v.40, n.2, p. 52-73, maio/agosto, 2019. 
NIETZSCHE, F. W. Fragmentos Póstumos: Volumen III (1882 - 1885). Edición española dirigida por Diego Sánchez Meca. Traducción, introducción y notas de Diego Sánches Meca y Jesús Conill; Madrid, Tecnos (Grupo Anaya S.A.), 2010.

NIETZSCHE, F. W. Fragmentos Póstumos: Volumen IV (1885 - 1889). Edición española dirigida por Diego Sánchez Meca. $2^{a}$ edición. Traducción, introducción y notas de Juan Luis Vermal y Joan B. Llinares; Madrid: Tecnos (Grupo Anaya S.A.), 2008.

NIETZSCHE, F. W. Assim Falou Zaratustra: Um livro para todos e para ninguém. Tradução, notas e posfácio de Paulo César de Souza. São Paulo: Companhia das Letras, 2011.

VIESENTEINER, J. L. Erlebnis (vivência): autobiografia ou autogenealogia? Sobre a "crítica da 'razão da minha vida"' em Nietzsche. In: Estudos Nietzsche, Curitiba, v. 1, n. 2, p. 327-353, jul./dez. 2010. Disponível em: <www2.pucpr. $\mathrm{br} / \mathrm{reol} /$ index.php/ESTUDOSNIETZSCHE?ddl=5027\&dd99=pdf $>$. Acesso em 07 de junho de 2016.

VIESENTEINER, J. L. O conceito de vivência (Erlebnis) em Nietzsche: gênese, significado e recepção. In: Kriterion, Belo Horizonte, v. 54, n. 127, p. 141-155, June 2013 . Disponível em <http://www.scielo.br/scielo.php?script=sci_ arttext\&pid=S0100-512X2013000100008\&lng=en\&nrm=iso $>$. Acesso em 07 de junho de 2016. http://dx.doi.org/10.1590/S0100-512X2013000100008.

Recebido em 30/05/2019

Aceito em 25/07/2019 